NBER WORKING PAPER SERIES

A BRAZILIAN-TYPE DEBT CRISIS: SIMPLE ANALYTICS

\author{
Assaf Razin \\ Efraim Sadka \\ Working Paper 9606 \\ http://www.nber.org/papers/w9606 \\ NATIONAL BUREAU OF ECONOMIC RESEARCH \\ 1050 Massachusetts Avenue \\ Cambridge, MA 02138 \\ April 2003
}

The views expressed herein are those of the authors and not necessarily those of the National Bureau of Economic Research.

C2003 by Assaf Razin and Efraim Sadka. All rights reserved. Short sections of text not to exceed two paragraphs, may be quoted without explicit permission provided that full credit including Cnotice, is given to the source. 
A Brazilian-Type Debt Crisis: Simple Analytics

Assaf Razin and Efraim Sadka

NBER Working Paper No. 9606

April 2003

JEL No. F3

\section{$\underline{\text { ABSTRACT }}$}

We develop a model that captures important features of debt crises of the Brazilian type. Its applicability to Brazil lies in the fact that (1) macro fundamentals were sound in the wake of the crisis (e .g., a non-negligible primary surplus, a relatively low debt/GDP ratio, low inflation, etc.); and (2) the trigger for the crisis appears to be the forthcoming elections, with an expected regime change.

Assaf Razin

Eitan Berglas School of Economics

Tel Aviv University

Tel Aviv 69978

Israel

and NBER

razin@post.tau.ac.il
Efraim Sadka

Tel Aviv University

Tel Aviv 69978

Israel

sadka@post.tau.ac.il 


\title{
A Brazilian-Type Debt Crisis: Simple Analytics*
}

\author{
Assaf Razin ${ }^{\dagger}$ and Efraim Sadka ${ }^{\ddagger}$
}

February 2003

\begin{abstract}
A bstract
We develop a model that captures important features of debt crises of the Brazilian type. Its applicability to Brazil lies in the fact that (1) macro fundamentals were sound in the wake of the crisis (e .g., a non-negligible primary surplus, a relatively low debt/GDP ratio, low inflation, etc.); and (2) the trigger for the crisis appears to be the forthcoming elections, with an expected regime change.
\end{abstract}

\section{Introduction}

Brazil public finances appeared to have been in shambles prior to the election in October 2002. The IMF accord from August 2002 gave Brazil a critical boost, providing the central bank with a total additional $\$ 16$ billion in international reserves to defend its weak currency and thereby to contain the explosion of dollar-linked public debt service. ${ }^{1}$ The package also includes a promise to increase the loan to $\$ 30$ billion, if the primary surplus is increased. Three-quarters of Brazil's debt is in domestic currency, and around a third of this debt is indexed to the dollar. Therefore, the policy challenge was not only the strength of Brazil's currency, but also the level and volatility of domestic interest rates. Because most of Brazil's local currency debt is short-term, and thus effectively indexed to the rate of interest, Brazil seems to have been vulnerable to self-fulfilling-expectations reversals in capital flows, with the country's risk ratings at the centre of the equilibrium shifts. Indeed, since the presidential elections

\footnotetext{
*This note was written while the two authors visited the Economic Policy Research Unit (EPRU) at the University of Copenhagen.

${ }^{\dagger}$ The Mario Henrique Simonsen Professor of Public Finance, Tel-Aviv University, Research Associate, NBER and Research Fellow, CEPR.

‡The Henry Kaufman Professor of International Capital Markets and Research Fellow, CESifo.

${ }^{1}$ Although only $\$ 6$ billion of the new IMF loan were available in 2002, Brazil's central bank will have more flexibility after the accord. The agreement cuts to $\$ 5$ billion (from $\$ 15$ billion) the minimum level of reserves it promises to hold. Thus, in effect, there is an additional $\$ 16$ billion the central bank can use to defend the currency.
} 
in October 2002, which brought to power the leftist Workers' Party that has a history of anti-market sloganeering, the new government has worked to reassure the markets that Brazil would pay its debts, curb its budget deficits and reduce inflation. By March 2003 Brazil's currency has appreciated and the risk premium that investors demand for holding Brazilian debt has dropped significantly (from more than 20 percentage point in October 2002 to 10 percentage points by March 2003). Did credit rating institutions contribute to an overreaction by the markets in the runup for the Brazil's 2002 election? The Economist (February 8th, 2003), though in a domestic regulation context, describes the potential circularity associated with ratings as follows:

"As ratings have been more widely used in regulation, they have begun to affect the market, in a version of Goodhart's law (that any variable chosen as a monetary-policy target immediately starts to behave differently). Because regulators and banks use ratings to assess credit risk, a rating downgrade can itself become a trigger requiring higher interest payments from a borrower or even driving it into bankruptcy. Similarly, rather as teachers often teach to the test, financial instruments are increasingly designed solely to carry a particular rating, not the other way round."

In this note we rationalize the sort of circularity involved in credit rating. Our main purpose is to develop a simple, textbook-like exposition of how could country credit ratings bring about unstable macroeconomic behavior, and to explore its implications for fiscal policy.

The main difference between this note and Razin and Sadka (2001) are: (1) Investment behavior in the former is new-classical, whereas investment behavior in the latter is subject to a costly state verification to accommodate for potential defaults (Townsend (1979)). (2) Fiscal policy implications are pursued in the former but not in the latter. (3) The main insight to be obtained from this note comes from a simple diagrammatic analysis, and the main argument is not hidden, perhaps, behind the algebra. This note is also related to Velasco (1996). His model, however, deals with a different macroeconomic phenomenon, and thus has also different fiscal policy implications.

The paper is organized as follows. Section 2 develops the model; Section 3 discusses the phenomenon of self-fulfilling credit ratings; and Section 4 points to corrective policies. Section 5 concludes.

\section{A Textbook Model}

Consider a small open economy that borrows in the world capital markets at a rate $r$ which includes a country-specific risk-premium. Suppose that the initial stock of capital of a representative firm is 
$(1-\delta) K_{0}$, where $\delta$ is the rate of depreciation and $K_{0}$ is previous period capital. With this stock at hand, the firm invests at present so as to adjust its capital stock to $K$ in order to maximize its value. This gives rise to a Bellman equation as follows:

$$
V\left[(1-\delta) K_{0}\right]=\operatorname{Max}_{K} \frac{1 / 2}{1+r} F(K)-\left[K-(1-\delta) K_{0}\right]+\frac{1}{1+r} \alpha V[(1-\delta) K]^{3 / 4},
$$

where $F$ is a production function, $V$ is a value function, $t$ is a current (distortionary) tax, and $\alpha$ is a parameter which captures expected future corporate taxes. Naturally, higher future taxes should reduce $\alpha$. The first-order condition is given by:

$$
(1-t) F^{\prime}(K)=r+\delta+(1-\alpha)(1-\delta)
$$

provided that $K>K_{0}$.

Why should $V^{\prime}()=$.1 ,as implied by Equation(2)? The derivative of the maximand in Equation (1) with respect to $\mathrm{K}$ yields:

$$
\frac{(1-t)}{(1+r)} F^{\prime}(K)-1+\frac{(1-\delta)}{(1+r)} \alpha V^{\prime}[(1-\delta) K]=0
$$

Differentiating equation (1) totally, using the first-order condition (The Envelope Theorem):

$$
(1-\delta) V^{\prime}\left[(1-\delta) K_{0}\right] d K_{0}=\left\{\frac{(1-t)}{(1+r)} F^{\prime}(K)-1+\frac{(1-\delta)}{(1+r)} \alpha V^{\prime}[(1-\delta) K]\right\} d K+(1-\delta) d K_{0} \rightarrow V^{\prime}\left[(1-\delta) K_{0}\right]=1 .
$$

Thus, the derivative of the function $V^{\prime}($.$) must always be equal to one.$

Because investment is irreversible no new investment occurs when

$$
(1-t) F^{\prime}\left((1-\delta) K_{0}\right)<r+\delta+(1-\alpha)(1-\delta)
$$

The country's credit rating is external to our (identical) competitive firms, and depends on some aggregate (macro) economic variablesthat characterize the macroeconomic state of the country. Suppose that these macro variables are two. The first variable is the growth prospect of the economy as measured by the private stock of capital $(K)$. The second variable, the fiscal stance of the government, as measured by the primary surplus of the government. The higher the surplus, the less likely that the government will have to raise taxes in the future (that is, the higher also is $\alpha$ ). Accordingly, we assume that the country-specific interest rate is a decreasing function of both $K$ and $\alpha$ :

$$
r=r(K, \alpha) .
$$


Equation (4) is admittedly ad-hoc. But, this relationship is of a more general validity. It captures plausibly country risk rating based on aggregate macro variables, which yields a macroeconomic externality. It seems that this macroeconomic externality can be rationalized also in a more microfounded relationship of this sort.

Given the current fiscal stance of the government, and the implied future taxation as captured by $\alpha$ ); equations (2) [or condition (3)] and (4) equations (1) and (2) jointly determine $r$ and $K$. This is illustrated in Figure 1. Equation (2) is depicted by the curve AB (recall that $F$ is concave in $K$ ). Equation (4) is depicted by the curve $E_{1} E_{2} E_{3} H$.

There are potentially three equilibrium points - at $E_{1}, E_{2}$ and $E_{3}$. We can ignore the equilibrium at $E_{2}$, as it is not Walras-stable: If the stock of private capital rises above $K^{*}$, then $r=r(K, \alpha)$ falls, and each firm will tend to further increase its capital stock, moving further away from the equilibrium; a similar divergent process occurs if $K$ falls below $K^{*}$.

We refer to the equilibrium point at $E_{1}$ as the "bad" equilibrium. At this equilibrium the interest rate $\left.r[1-\delta) K_{0}, \alpha\right]$ is "high", above $(1-t) F^{\prime}\left(K_{0}\right)-\delta-(1-\alpha)(1-\delta)$, so that no firm will choose to invest at all as indicated by condition (3). We refer to the equilibrium at the point $E_{3}$ as a "good" equilibrium, in which $(1-t) F^{\prime}\left(K^{* *}\right)=r\left(K^{* *}, \alpha\right)+\delta+(1-\alpha)(1-\delta)$ and firms invest to increase their capital stock to $K^{* *}$.

\section{Self-Fulfilling Credit R atings}

Our textbook model can now be used to highlight the problem of self-fulfilling credit ratings. Suppose that the economy is initially at the "good" equilibrium: Private Domestic Investment is relatively high and the country-specific risk premium is relatively low. However, triggered by extrenous shocks the country may switch abruptly from this "good" equilibrium to the "bad" equilibrium. This may happen if some political factor serves to coordinate and to redirect market expectations. Such a political factor can be, for instance, an emergence of a rookie candidate for presidency whose future policies are uncertain in the eyes of international investors. Creditors then shift their beliefs about the country's credit worthiness and that would shift the market as well. These beliefs (that the country is at high credit risk) then become self-fulfilling. And, indeed, the country's investments dry out. ${ }^{2}$

\footnotetext{
${ }^{2}$ See Razin and Sadka (2001) for a similar mechanism that creates boom-bust equilibria. See also Calvo (1988) for an analysis of multiple equilibria associated with public debt service.
} 


\section{Corrective Policies}

A possible remedy is to raise the primary surplus. This would reduce future taxes, increase $\alpha$ and shift the curve $E_{1} E_{2} E_{3} F$ downward to $E_{1}^{\prime} E_{3}^{\prime}$. If the primary surplus is raised by cutting spending rather than by raising current taxes (in this case $t$ does not change), then the increase in $\alpha$ shifts out also the curve $A B$ to $A^{\prime} B^{\prime}$. In this case, the "bad" equilibrium (and also the unstable equilibrium) may disappear completely. Despite the initial decline in the country's credit rating that made the country land on the bad eqilibrium point $E_{1}$, the country moves to a new "good" equilibrium with an even better credit rating and more investment. If, however, the primary surplus is raised by increasing current taxes and not by cutting spendings (that is, by increasing $t$ ), then the curve $A B$ need not shift out at all. In this case, all three equilibria may remain, and the country is still vulnerable to self-fulfilling credit rating crunches.

Thus, raising the primary surplus as such is not necessarily a corrective policy for the Brazilian-type debt crisis. It is corrective if spendings are cut, but not if taxes are raised.

\section{Conclusion}

The simple model captures key features of the Brazil-type debt crisis. Its applicability to Brazil lies in two common features.

- Both in the model and in the case of Brazil, the macro fundamentals were not shaky (e.g., the primary surplus in Brazil in the wake of the crisis was around 2.25 percent of GNP).

- Both in the model and in the Brazilian case the "coordinator" of market expectations that shift the market outcome is extraneous to the economic fundamentals of the economy. In Brazil the expectations-"coordinator" appeared to have been forthcoming elections with a possibility of regime change.

Recently, To tackle the crisis Brazil raised its primary surplus target to $3.75-4.25 \%$ of GDP. Whether Brazil can return to robust growth seems to crucially depend on whether lower interest rates could be restored, as in our model. 


\section{R eferences}

[1] Razin, Assaf and Efraim Sadka (2001), "Country Risk and Capital Flow Reversals," Economic Letters, 72(1), July, 73-77.

[2] Calvo, Guillermo (1988), "Servicing the Public Debt: The Role of Expectations," A merican Economic R eview, 88, September.

[3] Townsend, Robert M.,(1979), "Optimal Conontracts and Competitive Markets with Costly State Verification," J ournal of Economic Theory, 21:265-293.

[4] Velasco, Andres (1996), "Animal Spirits, Investment and International Capital Movements," J ournal of International M oney and Finance 15(2), 221-237. 
Figure 1: The Stock of Private Capital and the Country-Specific Interest Rate

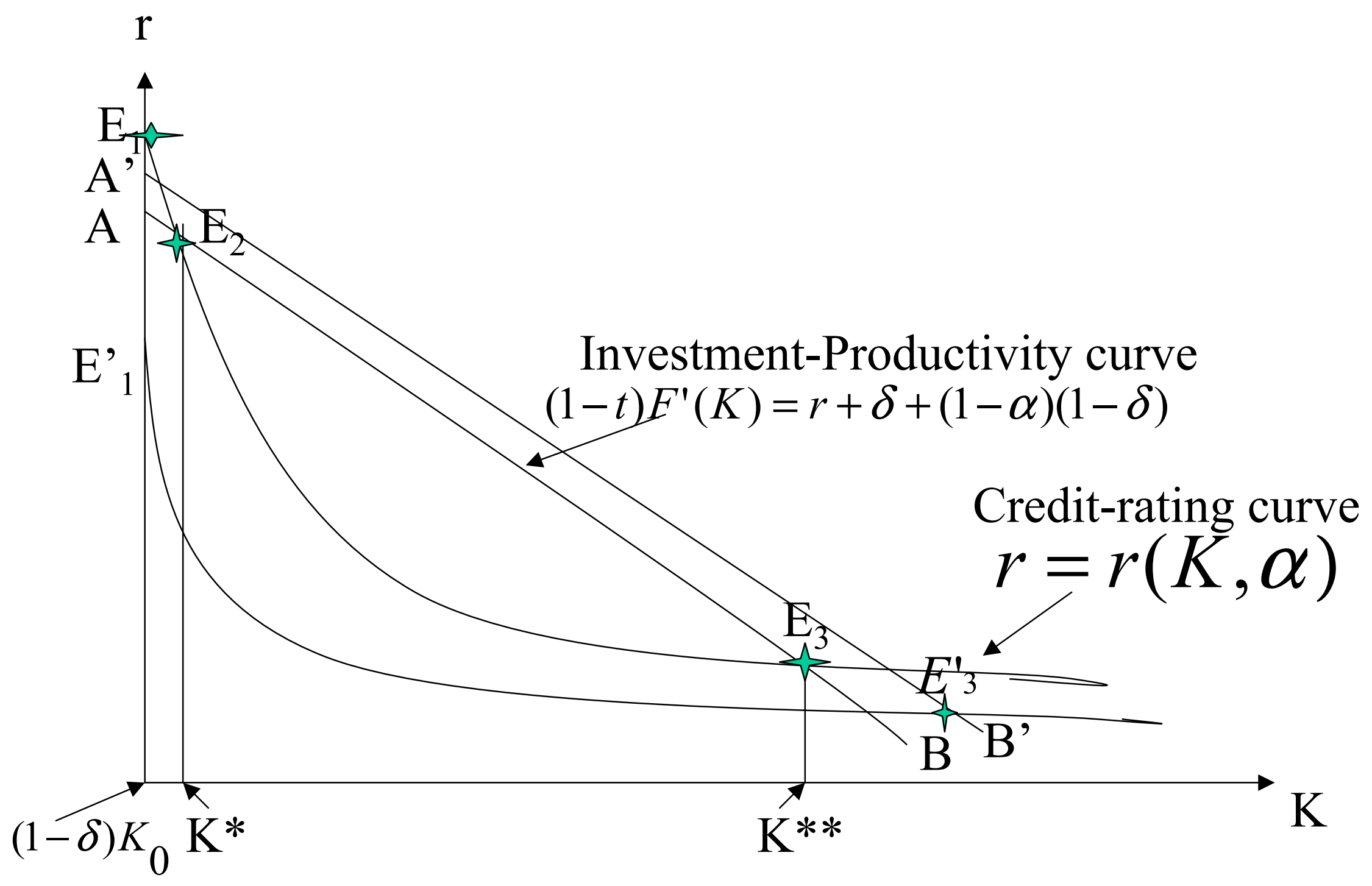

